Zeszyty Naukowe Szkoły Głównej Gospodarstwa Wiejskiego

Ekonomika i Organizacja Gospodarki Żywnościowej nr 117, 2017: 33-46

DOI 10.22630/EIOGZ.2017.117.3

Tomasz Siudek, Katarzyna Drabarczyk

Katedra Finansów

Szkoła Główna Gospodarstwa Wiejskiego w Warszawie

Aleksandra Jakubiec

Instytut Rynków i Konkurencji

Szkoła Główna Handlowa w Warszawie

\title{
Rozwój gospodarczy powiatów i podregionów województwa mazowieckiego
}

\section{Wstęp}

Rozwój gospodarczy w ekonomii definiowany jest w różny sposób. Może być on rozumiany jako wysiłek społeczności kraju w celu poprawy gospodarki i jakości życia ludności [Morse i Loveridge 1997] oraz jako działalność ludzką, która wiąże się z gospodarowaniem, a więc produkcją oraz podziałem dóbr i usług [Marciniak 2005]. Zainteresowanie poziomem rozwoju gospodarczego jest bardzo duże, ponieważ to od niego w dużej mierze zależą warunki życia ludności.

Nierównomierny dostęp do czynników produkcji powoduje zróżnicowanie poziomu rozwoju gospodarczego krajów, regionów czy też gmin. Wymaga on jednak pewnej kontroli i nieustannego monitorowania, ponieważ pogłębianie się różnic $\mathrm{w}$ rozwoju nie jest zjawiskiem pozytywnym. Zróżnicowanie to jest wynikiem wielu czynników, takich jak: wielkość zasobów naturalnych, rozwój przemysłu, gęstość zaludnienia czy też prowadzona polityka gospodarcza danego kraju. Różnorodność i charakter czynników sprawiają, że pomiar rozwoju gospodarczego nie jest prosty i jednoznacznie określony [Kubicki i Kulbaczewska 2009]. Duże różnice w poziomie rozwoju gospodarczego krajów stały się przedmiotem zainteresowania polityki Unii Europejskiej, która ma za zadanie redukować je, głównie za pomocą funduszy unijnych. Polityka gospodarcza, zarówno na poziomie krajowym, regionalnym czy lokalnym, ukierunkowana jest na zmniejszanie dysproporcji rozwojowych i stymulowanie rozwoju słabszych jednostek terytorialnych. Analiza dysproporcji oraz znajomość 
mocnych i słabych stron jednostek terytorialnych może ukierunkowywać ich działanie na ścieżkę rozwoju gospodarczego. Działania podejmowane przez jednostki terytorialne zależą od zrozumienia istoty i sensu rozwoju gospodarczego, ich zasobów finansowych oraz chęci działania i pomysłowości władz lokalnych [Nizioł 2008].

\section{Cel i metody badań}

Celem badań było określenie poziomu rozwoju gospodarczego powiatów i podregionów województwa mazowieckiego. Badania obejmują lata 2005 i 2014. Dane empiryczne pochodziły z bazy danych lokalnych Głównego Urzędu Statystycznego.

Poziom rozwoju gospodarczego w powiatach i podregionach określono przy wykorzystaniu miary rozwoju Hellwiga. Do budowy wskaźnika rozwoju przyjęto zmienne diagnostyczne, które poddano podstawowej weryfikacji statystycznej. Na podstawie współczynnika zmienności odrzucono te, które charakteryzowały się poziomem zmienności niższym niż $10 \%$. Ostatecznie do badania przyjęto 9 zmiennych, takich jak:

- $x_{1}$ - stopa bezrobocia [\%],

- $x_{2}$ - przeciętne miesięczne wynagrodzenie brutto [zł],

- $\quad x_{3}$ - dochody budżetu powiatu na 1 mieszkańca [zł],

- $\quad x_{4}$ - wydatki budżetu powiatu na 1 mieszkańca [zł],

- $\quad x_{5}$ - odsetek mieszkań wyposażonych w instalację wodociągową w ogólnej liczbie mieszkań [\%],

- $\quad x_{6}$ - odsetek mieszkań wyposażonych w centralne ogrzewanie w ogólnej liczbie mieszkań [\%],

- $x_{7}-$ długość dróg gminnych i powiatowych o twardej nawierzchni na $100 \mathrm{~km}^{2}[\mathrm{~km}]$,

- $\quad x_{8}$ - przeciętna powierzchnia użytkowa mieszkania na 1 osobę $\left[\mathrm{m}^{2}\right]$,

- $\quad x_{9}$ - produkcja sprzedana przemysłu ogółem na 1 mieszkańca [zł].

$\mathrm{Z}$ podanych zmiennych tylko $x_{1}$ uznano za destymulantę, a pozostałe zaliczono do stymulant rozwoju gospodarczego. Zmienne diagnostyczne wyrażone były w różnych jednostkach, dlatego zostały zestandaryzowane. Jest to proces niezbędny do umożliwienia ich porównywalności. Liczbowy opis zbioru powiatów można przedstawić w formie macierzy obserwacji:

$$
\mathbf{X}=\left[\begin{array}{cccc}
x_{11} & x_{12} & \ldots & x_{1 m} \\
x_{21} & x_{22} & \ldots & x_{2 m} \\
\ldots & \ldots & \ldots & \ldots \\
x_{n 1} & x_{n 2} & \ldots & x_{n m}
\end{array}\right]
$$


gdzie:

$x_{i j}$ - wartość $j$-tej zmiennej dla $i$-tego powiatu/podregionu, dla $i=1,2, \ldots, n^{1}$; $j=1,2, \ldots, m$.

Standaryzacji dokonano według wzoru [Hellwig 1968]:

$$
\begin{aligned}
& z_{i j}=\frac{\left(x_{i j}-\bar{x}_{j}\right)}{S_{j}} \\
& \bar{x}_{j}=\frac{1}{n} \sum_{i=1}^{n} x_{i j} \\
& S_{j}=\sqrt{\frac{1}{n} \sum_{i=1}^{n}\left(x_{i j}-\bar{x}_{j}\right)^{2}}
\end{aligned}
$$

gdzie:

$x_{i j}$ - zmienna diagnostyczna rozwoju gospodarczego powiatów i podregionów województwa mazowieckiego,

$z_{i j}$ - zestandaryzowana zmienna diagnostyczna rozwoju gospodarczego powiatów i podregionów województwa mazowieckiego,

$\bar{x}_{j}$ - średnia zmiennej diagnostycznej,

$S_{j}$ - odchylenie standardowe zmiennej diagnostycznej.

Po dokonaniu standaryzacji otrzymano macierz zestandaryzowanych wartości cech $-\mathbf{Z}$, gdzie $z_{i j}$ jest zestandaryzowaną wartością $x_{i j}$.

$$
\mathbf{Z}=\left[\begin{array}{cccc}
z_{11} & z_{12} & \ldots & z_{1 m} \\
z_{21} & z_{22} & \ldots & z_{2 m} \\
\ldots & \ldots & \ldots & \ldots \\
z_{n 1} & z_{n 2} & \ldots & z_{n m}
\end{array}\right]
$$

Na podstawie macierzy $\mathbf{Z}$ wyznaczono, tzw. wzorzec rozwoju (obiekt $X_{0}$ - hipotetyczny powiat lub podregion), który zawiera najkorzystniejsze wartości spośród cech $Z$, tj. $z_{0 j}=\max \left\{z_{i j}\right\}$, kiedy $Z_{j}$ jest stymulantą, oraz $z_{0 j}=\min \left\{z_{i j}\right\}$, kiedy $Z_{j}$ jest destymulantą. Następnie obliczono odległość euklidesową każdego ocenianego obiektu $X_{i}$ (powiatu lub podregionu) od wyznaczonego wzorca rozwoju $X_{0}$ według wzoru [Hellwig 1968]:

\footnotetext{
${ }^{1} \mathrm{~W}$ województwie mazowieckim są 42 powiaty i 8 podregionów.
} 


$$
q_{i}=\sqrt{\sum_{j=1}^{m}\left(z_{i j}-z_{0 j}\right)^{2}}
$$

gdzie:

$q_{i}$ - odległość euklidesowa $i$-tego obiektu od obiektu wzorcowego $X_{0}$.

Otrzymane wartości $q_{i}$ posłużyły do obliczenia wartości wskaźnika rozwoju Hellwiga $S_{i}$ według równania:

$$
\begin{aligned}
& S_{i}=1-\frac{q_{i}}{q_{0}} \\
& q_{0}=\bar{q}_{0}+2 S_{0} \\
& \bar{q}_{0}=\frac{1}{n} \sum_{i=1}^{n} q_{i} \\
& S_{0}=\sqrt{\frac{1}{n} \sum_{i=1}^{n}\left(q_{i}-\bar{q}_{0}\right)^{2}}
\end{aligned}
$$

gdzie:

$S_{i}$ - wartość wskaźnika rozwoju Hellwiga dla $i$-tego powiatu/podregionu,

$q_{0}$ - krytyczna odległość $i$-tego powiatu/podregionu od wzorca,

$\bar{q}_{0}$ - średnia arytmetyczna taksonomicznych odległości,

$S_{0}$ - odchylenie standardowe taksonomicznych odległości.

Wskaźnik rozwoju Hellwiga $S_{i}$ przyjmuje wartości z przedziału $(0 ; 1)$. Wartości bliższe 1 oznaczają wyższy poziom rozwoju i bliższe podobieństwo do wyznaczonego wzorca i na odwrót. Wyodrębniono 4 grupy powiatów pod względem rozwoju gospodarczego [Wysocki 2010]:

- I grupa - wysoki poziom rozwoju gospodarczego $-S_{i} \geq \bar{S}_{i}+S_{s i}$,

- II grupa - średni wyższy poziom rozwoju gospodarczego $-\bar{S}_{i} \leq S_{i}<\bar{S}_{i}+S_{s i}$, III grupa - średni niższy poziom rozwoju gospodarczego $-\bar{S}_{i}-S_{s i} \leq S_{i}<\bar{S}_{i}$, IV grupa - niski poziom rozwoju gospodarczego $-S_{i}<\bar{S}_{i}-S_{s i}$, gdzie:

$\bar{S}_{i}$ - średnia arytmetyczna wskaźnika rozwoju Hellwiga $S_{i}$, $S_{s i}$ - odchylenie standardowe wskaźnika rozwoju Hellwiga $S_{i}$. 


\section{Rozwój gospodarczy w teoriach ekonomii}

Ekonomiści opracowali wiele teorii na temat rozwoju gospodarczego, z których wynika, że wiele z nich ma charakter ogólnikowy, nieprecyzyjny i chaotyczny [Piasecki 2007]. Ze wglądu na dużą liczbę teorii rozwoju gospodarczego w pracy ukazano tylko niektóre z nich (tab. 1).

\section{Tabela 1}

Wybrane teorie rozwoju gospodarczego

\begin{tabular}{|c|c|c|}
\hline Teoria & Przedstawiciele & Główne tezy \\
\hline 1 & 2 & 3 \\
\hline $\begin{array}{l}\text { Klasyczne } \\
\text { teorie } \\
\text { rozwoju } \\
\text { gospodarczego }\end{array}$ & $\begin{array}{l}\text { Adam Smith, } \\
\text { David Ricardo, } \\
\text { Thomas Malthus, } \\
\text { John Stuart Mill }\end{array}$ & $\begin{array}{l}\text { Za główny element rozwoju gospodarczego uważali } \\
\text { postęp techniczny, który umożliwia efektywny podział } \\
\text { pracy, a tym samym wzrost jej wydajności. Wraz ze } \\
\text { wzrostem zysków, wzrasta również zatrudnienie } \\
\text { i całkowita wielkość płac, co zachęca robotników do } \\
\text { powiększania rodzin. }\end{array}$ \\
\hline $\begin{array}{l}\text { Teoria rozwoju } \\
\text { gospodarczego } \\
\text { Schumpetera }\end{array}$ & Joseph Schumpeter & $\begin{array}{l}\text { Rozwój gospodarczy jest możliwy, kiedy spełnia się } \\
\text { łącznie } 3 \text { warunki: istnienie twórczego przedsiebbiorcy, } \\
\text { wprowadzanie innowacji i korzystanie z kredytu. Ka- } \\
\text { pitalista musi szukać sytuacji do zdobycia bogactwa } \\
\text { i nie bać się ponieść skutków ewentualnego ryzyka. } \\
\text { Przedsiębiorca w celu podniesienia wartości firmy } \\
\text { musi ciagle wprowadzać innowacje, bo tylko one przy- } \\
\text { noszą wysokie zyski. }\end{array}$ \\
\hline $\begin{array}{l}\text { Teoria rozwoju } \\
\text { gospodarczego } \\
\text { Marksa }\end{array}$ & Karol Marks & $\begin{array}{l}\text { Rozwój gospodarczy jest ściśle uzależniony od postę- } \\
\text { pu technicznego, który ma istotny wpływ na poziom } \\
\text { akumulacji kapitału. Z kolei kluczowym czynnikiem } \\
\text { akumulacji kapitału jest niski poziom płac. Praca jest } \\
\text { wyłącznym źródłem wartości powstałej w procesie } \\
\text { produkcji. }\end{array}$ \\
\hline $\begin{array}{l}\text { Teoria stadiów } \\
\text { Rostowa }\end{array}$ & Walt Rostow & 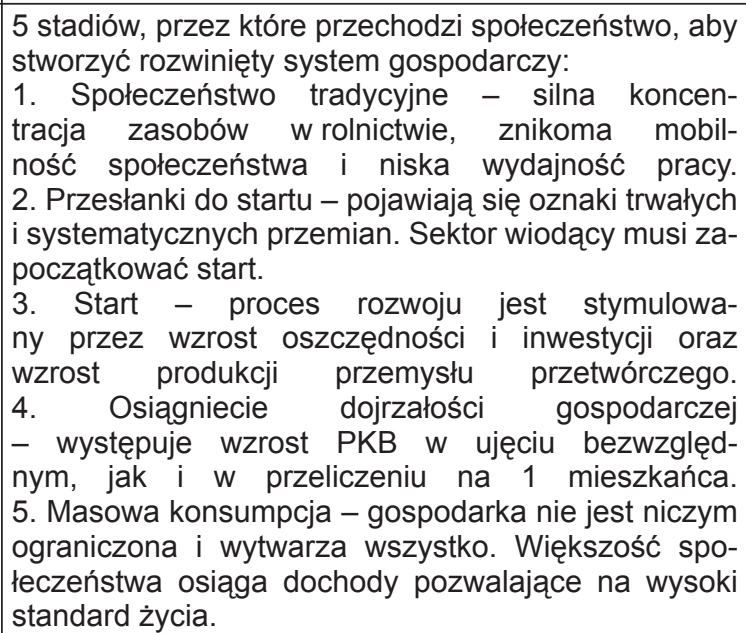 \\
\hline
\end{tabular}


Tabela $1 \mathrm{~cd}$.

\begin{tabular}{|c|c|c|}
\hline 1 & 2 & 3 \\
\hline $\begin{array}{l}\text { Teoria trzech } \\
\text { sektorów }\end{array}$ & $\begin{array}{l}\text { Jean Fourastié, } \\
\text { Colin Clark, } \\
\text { Allan Fisher }\end{array}$ & $\begin{array}{l}\text { Rozwój gospodarczy ma } 3 \text { stadia produkcji: } \\
\text { 1. Największe znaczenie ma produkcja rolna, leśnic- } \\
\text { two i przemysł wydobywczy (zaspokajanie podstawo- } \\
\text { wych potrzeb i zabezpieczanie odpowiedniej podaży } \\
\text { żywności). } \\
\text { 2. Skupienie produkcji na budownictwie i przemyśle } \\
\text { przetwórczym (rośnie zatrudnienie w przemyśle, na- } \\
\text { stępuje wzrost dochodów ludności przez co zaczyna } \\
\text { ona nabywać różne usługi). } \\
\text { 3. Dominacja usług (intensywny transfer zasobów } \\
\text { pracy i kapitału do sektora usług). Osiagnięcie trze- } \\
\text { ciego stadium oznacza osiagnięcie dojrzałości } \\
\text { w rozwoju gospodarczym. }\end{array}$ \\
\hline $\begin{array}{l}\text { Teoria } \\
\text { społeczeństwa } \\
\text { postindustrial- } \\
\text { nego }\end{array}$ & $\begin{array}{l}\text { Alain Touraine, } \\
\text { Daniel Bell }\end{array}$ & $\begin{array}{l}\text { Rozwój gospodarki i społeczeństwa dzieli się na } \\
3 \text { etapy: przedindustrialny, industrialny i postindu- } \\
\text { strialny. Rozwój gospodarczy mierzy się przez udział } \\
\text { sektora usług w gospodarce. Im wyższy jego udział, } \\
\text { tym wyższy rozwój. Główny zysk płynie z sektora } \\
\text { usług. Praca i kapitał zostają wyparte przez wiedzę. }\end{array}$ \\
\hline
\end{tabular}

Źródło: Opracowanie własne na podstawie przeglądu literatury.

Z przedstawionych teorii wynika, że są różne podejścia do badania rozwoju gospodarczego. Jedne teorie wskazują, że źródłem rozwoju jest praca, inne z kolei, że postęp technologiczny. Patrząc przez pryzmat sektorów, niski rozwój gospodarczy jest w sytuacji, w której w gospodarce dominuje rolnictwo, a wysoki w przypadku dużego udziału usług w gospodarce.

\section{Rozwój gospodarczy powiatów w świetle badań empirycznych}

Z literatury przedmiotu wynika, że było prowadzonych wiele badań z zakresu rozwoju gospodarczego powiatów (tab. 2). Jedne z nich skupiały się na określaniu zmian rozwoju w ujęciu czasowym i przestrzennym, drugie zaś identyfikowały czynniki na niego wpływające. Ze względu na brak jednej powszechnie akceptowalnej metody oceny, w badaniach nad rozwojem gospodarczym wykorzystywano rozmaite mierniki syntetyczne. Różnorodność doboru poszczególnych zmiennych diagnostycznych wchodzących w skład miernika syntetycznego prowadziła często do braku możliwości porównywania wyników badań. Nie oznacza to jednak, że takie mierniki są bezużyteczne. Ocena rozwoju jednostek terytorialnych może być przydatna w kształtowaniu krajowej, regionalnej i lokalnej polityki gospodarczej. Na podstawie wyników badań można określić najsłabiej i najmocniej rozwinięte kraje, regiony, powiaty czy też gminy. 
Tabela 2 przedstawia przegląd badań dotyczących lokalnego rozwoju gospodarczego na poziomie powiatów. Kwestią sporną w badaniach pozostaje analizowanie powiatów ziemskich wraz z miastami na prawach powiatów. W miastach powiatowych skupiona jest duża część potencjału społeczno-demograficznego, co może skutkować obniżeniem wskaźników rozwoju powiatów ziemskich przyległych do tych miast. Jak pokazują badania, miasta na prawach powiatów charakteryzują się wyższym poziomem rozwoju gospodarczego niż powiaty ziemskie [Bajorski i Tokarski 2011].

\section{Tabela 2}

Wyniki badań rozwoju powiatów w literaturze

\begin{tabular}{|c|c|}
\hline Autorzy & Konkluzja \\
\hline 1 & 2 \\
\hline $\begin{array}{l}\text { Bajorski, } \\
\text { Tokarski [2011] }\end{array}$ & $\begin{array}{l}\text { Badano powiaty województwa podkarpackiego na podstawie analizy prze- } \\
\text { strzennego zróżnicowania rozwoju ekonomicznego. Zróżnicowanie to roz- } \\
\text { patrywano na podstawie takich zmiennych, jak produkcja sprzedana prze- } \\
\text { mysłu na mieszkańca, wartość brutto środków trwałych per capita, inwesty- } \\
\text { cje na mieszkańca, płace i stopa bezrobocia w latach 2002-2008. Powiaty } \\
\text { grodzkie woj. podkarpackiego miały znacznie wyższy poziom rozwoju od } \\
\text { powiatów ziemskich. Najwyższe stopy wzrostu taksonomicznych wskaźni- } \\
\text { ków rozwoju ekonomicznego w badanym przedziale czasu występowały } \\
\text { w powiatach: stalowowolskim, mieleckim i sanockim, a najniższe w powia- } \\
\text { tach: krośnieńskim ziemskim, strzyżowskim, lubaczowskim, jarosławskim } \\
\text { i leskim. }\end{array}$ \\
\hline Dykas [2012] & $\begin{array}{l}\text { Badano rozwój powiatów województwa małopolskiego w latach } 2002- \\
-2008 \text {, wykorzystując cztery podstawowe zmienne makroekonomiczne: } \\
\text { stopę bezrobocia rejestrowanego, majatek trwały brutto per capita, inwe- } \\
\text { stycje per capita i płace. Najlepiej rozwinięty był powiat krakowski i powiaty } \\
\text { w bliskim otoczeniu stolicy województwa. Powiaty leżące we wschodniej } \\
\text { i w południowo-wschodniej części województwa były najsłabiej rozwinięte } \\
\text { pod względem ekonomicznym, ich cechą był wysoki odsetek osób zatrud- } \\
\text { nionych w rolnictwie. }\end{array}$ \\
\hline $\begin{array}{l}\text { Dykas, } \\
\text { Szewczyk } \\
{[2015]}\end{array}$ & $\begin{array}{l}\text { Badano } 101 \text { powiatów województw: lubelskiego, podkarpackiego, podla- } \\
\text { skiego, świętokrzyskiego i warmińsko-mazurskiego w latach 2002-2012. } \\
\text { Badania przeprowadzono na podstawie zmiennych: produkcji sprzedanej } \\
\text { przemysłu, wartości brutto środków trwałych, inwestycji per capita, śred- } \\
\text { niej płacy, stopy bezrobocia i liczby podmiotów wpisanych do rejestru } \\
\text { REGON na tysiąc mieszkańców. Najwyższy poziom rozwoju ekonomicz- } \\
\text { nego, mierzony zarówno wskaźnikiem taksonomicznym, jak i wartością } \\
\text { omawianych zmiennych notowany był w miastach na prawach powiatu, } \\
\text { będących stolicami badanych województw. Wysoki poziom rozwoju ekono- } \\
\text { micznego występował w pozostałych powiatach grodzkich, a niski poziom } \\
\text { w powiatach z dominacją rolnictwa. }\end{array}$ \\
\hline $\begin{array}{l}\text { Fic, Malinow- } \\
\text { ski, Roszkow- } \\
\text { ska-Hołysz } \\
{[2011]}\end{array}$ & $\begin{array}{l}\text { Badano powiaty województwa lubuskiego w latach } 2002-2008 \text {. Podstawa } \\
\text { oceny był syntetyczny miernik rozwoju. Analiza wykazała znaczne różnice } \\
\text { między powiatami. Najwyższy rozwój wykazywał powiat grodzki - Zielona } \\
\text { Góra, a najsłabszy powiat krośnieński. }\end{array}$ \\
\hline
\end{tabular}


Tabela $2 \mathrm{~cd}$.

\begin{tabular}{|c|c|}
\hline 1 & 2 \\
\hline $\begin{array}{l}\text { Jabłoński, } \\
\text { Tokarski [2010] }\end{array}$ & $\begin{array}{l}\text { Badano powiaty w całej Polsce w latach } 2002-2007 \text {. Na podstawie mier- } \\
\text { ników taksonomicznych bazujących na odległościach w przestrzeni eu- } \\
\text { klidesowej uznano, że najlepiej rozwiniętymi powiatami były powiaty } \\
\text { w aglomeracjach dużych miast i powiaty grodzkie, które do } 1999 \text { roku peł- } \\
\text { niły funkcję miast wojewódzkich. Z kolei najmniej rozwiniętymi powiatami } \\
\text { były jednostki położone na obszarach rolniczych w województwach: war- } \\
\text { mińsko-mazurskim, kujawsko-pomorskim, zachodniopomorskim, dolnośla-- } \\
\text { skim i podkarpackim. }\end{array}$ \\
\hline Łuczak [2016] & $\begin{array}{l}\text { Badano powiaty ziemskie województwa wielkopolskiego w latach } 2005 \\
\text { i } 2013 \text {. Do oceny pozycji rozwojowej zastosowano metodę Hellwiga } \\
\text { w kwantyfikowalnej metodzie SWOT. Wyodrębniono cztery główne typy po- } \\
\text { zycji rozwojowych. Typ rozwojowy agresywny ujawnił się w } 13 \text { powiatach, } \\
\text { a w szczególności w poznańskim i nowotomyskim. Typ konkurencyjnej po- } \\
\text { zycji rozwojowej występował w powiecie konińskim, zaś typ konserwatyw- } \\
\text { nej pozycji rozwojowej słabo zaznaczył się w } 5 \text { powiatach oddalonych od } \\
\text { centrów miejskich. W } 9 \text { powiatach położonych we wschodniej części woje- } \\
\text { wództwa ujawnił się typ pozycji rozwojowej defensywnej (kaliskim, kolskim, } \\
\text { słupeckim, pleszewskim i złotowskim). }\end{array}$ \\
\hline Nizioł [2008] & $\begin{array}{l}\text { Badano powiaty województwa lubelskiego w } 2006 \text { roku. Na podstawie } \\
9 \text { zmiennych zbudowano miernik rozwoju Hellwiga. Najlepszym pod tym } \\
\text { względem okazał się powiat grodzki Lublin, a pozostałe powiaty grodzkie } \\
\text { (Zamość, Chełm, Biała Podlaska) były gorsze od powiatów ziemskich - pu- } \\
\text { ławskiego, łęczyńskiego i świdnickiego. Najsłabszym pod względem roz- } \\
\text { woju był powiat hrubieszowski. W badaniu wykazano duże zróżnicowanie } \\
\text { między powiatami. }\end{array}$ \\
\hline Siudek [2009] & $\begin{array}{l}\text { Badano powiaty województwa mazowieckiego w latach 2003-2007. Zasto- } \\
\text { sowano analizę czynnikowa. Oszacowane syntetyczne wskaźniki wskazu- } \\
\text { ją, że najsilniejszy rozwój gospodarczy występował w miastach na prawach } \\
\text { powiatów, tj. w Warszawie, Radomiu, Płocku i Siedlcach, oraz w powiatach } \\
\text { piaseczyńskim i pruszkowskim, a najsłabszy w powiatach: ostrowskim, ło- } \\
\text { sickim, zwoleńskim, lipskim, białobrzeskim i żuromińskim. Na obszarach } \\
\text { o najwyższym rozwoju gospodarczym głównymi stymulantami były: liczba } \\
\text { ludności, liczba podmiotów gospodarczych w sektorze publicznym i pry- } \\
\text { watnym, przeciętna powierzchnia użytkowa mieszkania, zużycie gazu na } \\
1 \text { gospodarstwo domowe, przyrost naturalny na } 1000 \text { osób, liczba uczniów } \\
\text { przypadających na } 1 \text { komputer w szkołach podstawowych, liczba ludno- } \\
\text { ści na } 1 \text { miejsce w kinach, liczba obiektów noclegowych - pensjonatów. } \\
\text { Na obszarach o najniższym poziomie rozwoju gospodarczego głównymi } \\
\text { destymulantami były: słaby rozwój przemysłu i usług, niskotowarowe rol- } \\
\text { nictwo, niskie nakłady inwestycyjne, niskie dochody ludności i wysokie } \\
\text { bezrobocie. }\end{array}$ \\
\hline
\end{tabular}

Źródło: Opracowanie własne na podstawie przeglądu literatury. 
Z tabeli 2 wynika, że najbardziej rozwiniętymi powiatami były powiaty grodzkie, a najmniej rozwiniętymi powiaty ziemskie, w których dominującą działalnością gospodarczą było rolnictwo. W zależności od poszczególnych badań wykorzystywane były różne zmienne diagnostyczne rozwoju gospodarczego powiatów.

\section{Rozwój gospodarczy powiatów województwa mazowieckiego - wyniki własnych badań empirycznych}

Na podstawie wskaźnika rozwoju Hellwiga określono poziom rozwoju gospodarczego powiatów województwa mazowieckiego (tab. 3). Zarówno w 2005, jak i w 2014 roku spośród powiatów grodzkich najwyższym poziomem rozwoju gospodarczego charakteryzowała się Warszawa, a najniższym Radom, który był szybciej rozwinięty niż niektóre powiaty ziemskie. W opracowanym rankingu przed powiatem grodzkim Radom znalazły się powiaty ziemskie bezpośrednio przylegające do Warszawy, takie jak: pruszkowski, piaseczyński i warszawski zachodni. Najsłabszymi pod względem rozwoju gospodarczego w 2005 i w 2014 roku okazały się powiaty: zwoleński, radomski, siedlecki i szydłowiecki, które znajdują się blisko granicy administracyjnej województwa mazowieckiego. Największy wzrost wskaźnika rozwoju w badanych latach nastąpił w powiecie wyszkowskim, a największy spadek w powiecie kozienickim. W 2005 roku różnica między najbardziej i najmniej rozwiniętym powiatem wynosiła 0,69, a w 2014 roku 0,71 . Na tej podstawie można stwierdzić, że nieznacznie pogłębiła się dysproporcja między powiatami pod względem stopnia rozwoju gospodarczego.

\section{Tabela 3}

Ranking powiatów województwa mazowieckiego ze względu na poziom wskaźnika rozwoju Hellwiga

\begin{tabular}{|c|c|c|c|c|c|c|}
\hline Nazwa powiatu & 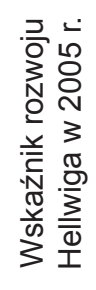 & 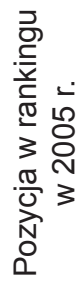 & 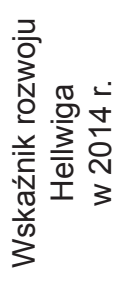 & 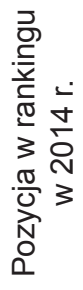 & 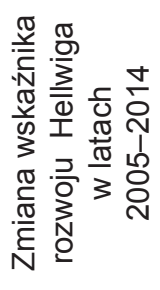 & 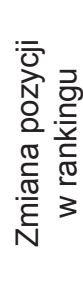 \\
\hline 1 & 2 & 3 & 4 & 5 & 6 & 7 \\
\hline m. Warszawa & 0,759 & 1 & 0,785 & 1 & 0,026 & - \\
\hline m. Ostrołęka & 0,513 & 2 & 0,558 & 2 & 0,045 & - \\
\hline m. Płock & 0,457 & 3 & 0,482 & 4 & 0,025 & $\downarrow$ \\
\hline m. Siedlce & 0,455 & 4 & 0,512 & 3 & 0,057 & $\uparrow$ \\
\hline
\end{tabular}


42

Tabela $3 \mathrm{~cd}$.

\begin{tabular}{|c|c|c|c|c|c|c|}
\hline 1 & 2 & 3 & 4 & 5 & 6 & 7 \\
\hline Pruszkowski & 0,455 & 5 & 0,423 & 6 & $-0,032$ & $\downarrow$ \\
\hline Piaseczyński & 0,406 & 6 & 0,435 & 5 & 0,029 & $\uparrow$ \\
\hline Warszawski zachodni & 0,405 & 7 & 0,412 & 7 & 0,007 & - \\
\hline Grodziski & 0,364 & 8 & 0,372 & 9 & 0,008 & $\downarrow$ \\
\hline m. Radom & 0,347 & 9 & 0,379 & 8 & 0,032 & $\uparrow$ \\
\hline Sochaczewski & 0,324 & 10 & 0,294 & 13 & $-0,030$ & $\downarrow$ \\
\hline Legionowski & 0,315 & 11 & 0,308 & 12 & $-0,007$ & $\downarrow$ \\
\hline Kozienicki & 0,309 & 12 & 0,235 & 21 & $-0,074$ & $\downarrow$ \\
\hline Otwocki & 0,299 & 13 & 0,310 & 11 & 0,011 & $\uparrow$ \\
\hline Nowodworski & 0,298 & 14 & 0,319 & 10 & 0,021 & $\uparrow$ \\
\hline Grójecki & 0,284 & 15 & 0,285 & 14 & 0,001 & $\uparrow$ \\
\hline Wołomiński & 0,261 & 16 & 0,247 & 18 & $-0,014$ & $\downarrow$ \\
\hline Garwoliński & 0,255 & 17 & 0,248 & 17 & $-0,007$ & - \\
\hline Żyrardowski & 0,253 & 18 & 0,254 & 16 & 0,001 & $\uparrow$ \\
\hline Ciechanowski & 0,244 & 19 & 0,264 & 15 & 0,020 & $\uparrow$ \\
\hline Miński & 0,230 & 20 & 0,226 & 22 & $-0,004$ & $\downarrow$ \\
\hline Łosicki & 0,221 & 21 & 0,222 & 24 & 0,001 & $\downarrow$ \\
\hline Lipski & 0,220 & 22 & 0,213 & 25 & $-0,007$ & $\downarrow$ \\
\hline Sokołowski & 0,213 & 23 & 0,239 & 20 & 0,026 & $\uparrow$ \\
\hline Przasnyski & 0,208 & 24 & 0,205 & 28 & $-0,003$ & $\downarrow$ \\
\hline Płoński & 0,206 & 25 & 0,222 & 23 & 0,016 & $\uparrow$ \\
\hline Ostrowski & 0,195 & 26 & 0,198 & 29 & 0,003 & $\downarrow$ \\
\hline Sierpecki & 0,191 & 27 & 0,181 & 35 & $-0,010$ & $\downarrow$ \\
\hline Pułtuski & 0,191 & 28 & 0,193 & 30 & 0,002 & $\downarrow$ \\
\hline Mławski & 0,185 & 29 & 0,183 & 34 & $-0,002$ & $\downarrow$ \\
\hline Białobrzeski & 0,183 & 30 & 0,211 & 26 & 0,028 & $\uparrow$ \\
\hline Żuromiński & 0,181 & 31 & 0,184 & 33 & 0,003 & $\downarrow$ \\
\hline Wyszkowski & 0,180 & 32 & 0,243 & 19 & 0,063 & $\uparrow$ \\
\hline Węgrowski & 0,176 & 33 & 0,181 & 36 & 0,005 & $\downarrow$ \\
\hline Ostrołęcki & 0,174 & 34 & 0,185 & 31 & 0,011 & $\uparrow$ \\
\hline Gostyniński & 0,174 & 35 & 0,184 & 32 & 0,010 & $\uparrow$ \\
\hline Płocki & 0,165 & 36 & 0,206 & 27 & 0,041 & $\uparrow$ \\
\hline Makowski & 0,164 & 37 & 0,164 & 38 & 0,000 & $\downarrow$ \\
\hline Przysuski & 0,150 & 38 & 0,167 & 37 & 0,017 & $\uparrow$ \\
\hline Zwoleński & 0,131 & 39 & 0,150 & 39 & 0,019 & - \\
\hline Radomski & 0,106 & 40 & 0,137 & 40 & 0,031 & - \\
\hline Siedlecki & 0,104 & 41 & 0,100 & 41 & $-0,004$ & - \\
\hline Szydłowiecki & 0,068 & 42 & 0,075 & 42 & 0,007 & - \\
\hline
\end{tabular}

Źródło: Badania własne. 
Wykorzystując wskaźnik rozwoju Hellwiga, podzielono powiaty województwa mazowieckiego na 4 grupy (tab. 4). W latach 2005 i 2014 do I grupy o najniższym rozwoju gospodarczym zakwalifikowano te same powiaty ( 7 jednostek). W 2014 r. z grupy II odpadł powiat kozienicki, którego wartość wskaźnika Hellwiga spadła najbardziej spośród wszystkich powiatów. Pozytywne było to, że w grupie IV o najniższym rozwoju gospodarczym liczba powiatów zmniejszyła się z 4 do 2. Większość powiatów województwa mazowieckiego znajdowała się w grupie III i IV. Powiaty te charakteryzowały się wskaźnikami rozwoju Hellwiga niższymi niż średni dla wszystkich powiatów województwa mazowieckiego.

\section{Tabela 4}

Powiaty województwa mazowieckiego w podziale na grupy według wskaźnika rozwoju Hellwiga

\begin{tabular}{|c|c|c|c|c|}
\hline Grupa & Powiaty w 2005 r. & $\begin{array}{l}\text { Liczba } \\
\text { powiatów } \\
\text { w grupie }\end{array}$ & Powiaty w 2014 r. & $\begin{array}{l}\text { Liczba } \\
\text { powiatów } \\
\text { w grupie }\end{array}$ \\
\hline 1 & $\begin{array}{l}\text { m. Warszawa }[0,759], \\
\text { m. Ostrołęka, m. Płock, } \\
\text { m. Siedlce, pruszkowski, } \\
\text { piaseczyński, warszawski } \\
\text { zachodni }[0,405]\end{array}$ & $7(17 \%)$ & $\begin{array}{l}\text { m. Warszawa [0,785], } \\
\text { m. Ostrołęka, m. Siedlce, } \\
\text { m. Płock, piaseczyński, } \\
\text { pruszkowski, warszawski } \\
\text { zachodni }[0,412]\end{array}$ & $7(17 \%)$ \\
\hline II & $\begin{array}{l}\text { grodziski }[0,364] \text {, } \\
\text { m. Radom, sochaczewski, } \\
\text { legionowski, kozienicki, } \\
\text { otwocki, nowodworski, gró- } \\
\text { jecki }[0,284]\end{array}$ & $8(19 \%)$ & $\begin{array}{l}\text { m. Radom }[0,379] \text {, grodzi- } \\
\text { ski, nowodworski, otwocki, } \\
\text { legionowski, sochaczewski, } \\
\text { grójecki }[0,285]\end{array}$ & $7(17 \%)$ \\
\hline III & $\begin{array}{l}\text { wołomiński [0,261], gar- } \\
\text { woliński, żyrardowski, cie- } \\
\text { chanowski, miński, łosicki, } \\
\text { lipski, sokołowski, przasny- } \\
\text { ski, płoński, ostrowiecki, } \\
\text { sierpecki, pułtuski, mławski, } \\
\text { białobrzeski, żuromiński, } \\
\text { wyszkowski, węgrowski, } \\
\text { ostrołęcki, gostyniński, } \\
\text { płocki, makowski, przysuski } \\
\text { [0,150] }\end{array}$ & $23(55 \%)$ & $\begin{array}{l}\text { ciechanowski [0,264], żyrar- } \\
\text { dowski, garwoliński, woło- } \\
\text { miński, wyszkowski, soko- } \\
\text { łowski, kozienicki, miński, } \\
\text { płoński, łosicki, lipski, biało- } \\
\text { brzeski, płocki, przasnyski, } \\
\text { ostrowski, pułtuski, ostrołęc- } \\
\text { ki, gostyniński, żuromiński, } \\
\text { mławski, sierpecki, węgrow- } \\
\text { ski, przysuski, makowski, } \\
\text { zwoleński, radomski }[0,137] \\
\end{array}$ & $26(62 \%)$ \\
\hline IV & $\begin{array}{l}\text { zwoleński }[0,131], \text { radom- } \\
\text { ski, siedlecki, szydłowiecki } \\
{[0,068]}\end{array}$ & $4(10 \%)$ & $\begin{array}{l}\text { siedlecki }[0,100] \text {, szydłowiec- } \\
\text { ki }[0,075]\end{array}$ & $2(5 \%)$ \\
\hline
\end{tabular}

Ze względu na zaokraglenia liczb, suma procentów jest większa od 100.

Źródło: Badania własne. 


\section{4}

Z tabeli 5 wynika, że najlepszymi podregionami województwa mazowieckiego ze względu na poziom i zmiany wskaźnika rozwoju Hellwiga były: m.st. Warszawa i podregion warszawski zachodni, a najgorszymi podregion radomski i ciechanowski.

Tabela 5

Rozwój gospodarczy w podregionach województwa mazowieckiego w latach 2005 i 2014

\begin{tabular}{|l|c|c|c|}
\hline Podregion & $\begin{array}{c}\text { Wskaźnik rozwoju } \\
\text { Hellwiga w 2005 r. }\end{array}$ & $\begin{array}{c}\text { Wskaźnik rozwoju } \\
\text { Hellwiga w 2014 r. }\end{array}$ & $\begin{array}{c}\text { Zmiana } \\
2014 / 2005\end{array}$ \\
\hline m.st. Warszawa & 0,897 & 0,927 & 0,031 \\
\hline Warszawski zachodni & 0,449 & 0,471 & 0,022 \\
\hline Płocki & 0,371 & 0,387 & 0,016 \\
\hline Warszawski wschodni & 0,362 & 0,375 & 0,013 \\
\hline Ostrołęcki & 0,328 & 0,348 & 0,021 \\
\hline Siedlecki & 0,320 & 0,336 & 0,016 \\
\hline Ciechanowski & 0,288 & 0,300 & 0,012 \\
\hline Radomski & 0,263 & 0,256 & $-0,007$ \\
\hline
\end{tabular}

Źródło: Badania własne.

\section{Podsumowanie i wnioski końcowe}

1. Na podstawie wskaźnika rozwoju Hellwiga można stwierdzić, że rozwój gospodarczy powiatów w województwie mazowieckim charakteryzował się dużym zróżnicowaniem. Pogłębiła się dysproporcja między najbardziej i najmniej rozwiniętymi powiatami. Poziom wskaźnika rozwoju Hellwiga dla najbardziej rozwiniętego powiatu był dziesięciokrotnie wyższy niż dla powiatu najsłabiej rozwiniętego.

2. Najmocniej rozwiniętymi powiatami województwa mazowieckiego były powiaty grodzkie i ziemskie, graniczące z powiatem m.st. Warszawa, a najsłabiej powiaty położone $\mathrm{w}$ południowej części województwa mazowieckiego. Stymulantą rozwoju gospodarczego powiatów województwa mazowieckiego był głównie rozwój przemysłu, warunkujący wysoki poziom zatrudnienia, a destymulantą była przede wszystkim dominacja rolnictwa w powiatach.

3. Z badań wynika, że zmiany rozwoju gospodarczego badanych jednostek terytorialnych są bardzo powolne. Biorąc pod uwagę rozwój gospodarczy powiatów województwa mazowieckiego należy stwierdzić, że zmiany ich pozycji w rankingu pomiędzy 2005 i 2014 rokiem były niewielkie. Wyjątkiem było kilka powiatów, takich jak: kozienicki, sierpecki i płocki. 
4. Opracowany ranking rozwoju gospodarczego powiatów województwa mazowieckiego może być wykorzystany w polityce regionalnej państwa w zakresie redystrybucji środków unijnych. Skierowanie większych środków finansowych z Unii Europejskiej na obszary o niskim rozwoju gospodarczym pozwoliłoby na zmniejszenie dysproporcji między powiatami najuboższymi i najbogatszymi. Metropolia, jaką jest Warszawa, zawyża wskaźniki rozwoju gospodarczego województwa, co powoduje, że najuboższe jego powiaty uzyskują mniej środków unijnych niż faktycznie powinny dostawać. Wydaje się, że problem dysproporcji rozwoju gospodarczego w polityce regionalnej należałoby rozpatrywać nie w skali województw, tylko mniejszych obszarów, np. podregionów czy nawet powiatów.

\section{Literatura}

BAJORSKI B., TOKARSKI T., 2011: Przestrzenne zróżnicowanie rozwoju ekonomicznego powiatów woj. podkarpackiego, Wiadomości Statystyczne 5, 47-69.

DYKAS P., 2012: Zróżnicowanie rozwoju powiatów w woj. małopolskim, Wiadomości Statystyczne 2, 67-77.

DYKAS P., SZEWCZYK M., 2015: Zróżnicowanie rozwoju ekonomicznego powiatów Polski Wschodniej, Studia i Materiały. Miscellanea Oeconomicae I, 4, 37-55.

FIC M., MALINOWSKI M., ROSZKOWSKA-HOŁYSZ D., 2011: Zróżnicowanie społeczno-gospodarcze powiatów regionu lubuskiego, Studia Ekonomiczne. Uniwersytet Ekonomiczny w Katowicach. Przegląd wybranych zagadnień rozwoju ekonomiczno-społecznego 79, 31-42.

HELLWIG Z., 1968: Zastosowanie metody taksonomicznej do typologicznego podziału krajów ze względu na poziom ich rozwoju oraz zasoby i strukturę wykwalifikowanych kadr, Przegląd Statystyczny 15, 4, 307-327.

JABŁOŃSKI Ł., TOKARSKI T., 2010: Taksonomiczne wskaźniki przestrzennego zróżnicowania rozwoju powiatów, Studia Prawno-Ekonomiczne 81, 261-289.

KUBICKI R., KULBACZEWSKA M., 2009: Zróżnicowanie rozwoju gospodarczego powiatów województwa zachodniopomorskiego, Zeszyty Naukowe Uniwersytetu Szczecińskiego. Ekonomiczne Problemy Usług 31, 1. Ekonomiczne i organizacyjne instrumenty wspierania rozwoju lokalnego i regionalnego. Finanse, rachunkowość, przedsiębiorczość, 112-119.

ŁUCZAK A., 2016: Ocena pozycji rozwojowej powiatów z wykorzystaniem zmodyfikowanej metody SWOT, Wiadomości Statystyczne 4, 50-65.

MARCINIAK S. (red.), 2005: Makro- $i$ mikroekonomia. Podstawowe problemy, PWN, Warszawa.

MORSE G., LOVERIDGE S., 1997: Implementing local business retention and expansion visitation programs, Northeast Regional Center for Rural Development. NERCRD Publication 72, University Park, P.A. 
NIZIOŁ A., 2008: Zróżnicowanie poziomu rozwoju społeczno-gospodarczego powiatów województwa lubelskiego, Barometr Regionalny 3(13), 77-84.

PIASECKI R., 2007: Ekonomia rozwoju, PWE, Warszawa.

SIUDEK T., 2009: Rozwój gospodarczy na przykładzie powiatów województwa mazowieckiego - aspekty teoretyczne i praktyczne, Roczniki Naukowe Stowarzyszenia Ekonomistów Rolnictwa i Agrobiznesu 11, 4, 305-311.

WYSOCKI F., 2010: Metody taksonomiczne w rozpoznawaniu typów ekonomicznych rolnictwa i obszarów wiejskich, Wydawnictwo Uniwersytetu Przyrodniczego w Poznaniu, Poznań.

\title{
Abstrakt
}

Głównym celem pracy było określenie poziomu rozwoju gospodarczego powiatów i podregionów województwa mazowieckiego w latach 2005 i 2014. W pracy zastosowano miernik rozwoju Hellwiga. Z uzyskanych danych wynika, że najbardziej rozwiniętymi powiatami były miasta na prawach powiatów, a najmniej rozwiniętymi powiaty ziemskie położone w południowej części województwa mazowieckiego. Najbardziej rozwinięte były podregiony warszawskie, a najmniej podregiony ciechanowski i radomski.

Słowa kluczowe: rozwój gospodarczy, powiaty, województwo mazowieckie

\section{Economic development of the counties and subregions of Masovian province}

\begin{abstract}
The main aim of this study was to determine the level of economic development of the counties and subregions of Masovian province in the years 2005 and 2014. The study used Hellwig measure of development. The obtained data show that the most developed counties were the cities at county rank, and the least developed were land counties in the southern part of the Mazovia province. The most developed were Warsaw subregions, and the least Radom and Ciechanów subregions.
\end{abstract}

Key words: economic development, counties, Masovian district 